Pomáhajúce profesie, roč. 2, č. 1, 2019, 5-16

\title{
HEALTH LITERACY OF THE POOR
}

\author{
Alena Kajanová, Zuzana Řimnáčová1 \\ ${ }^{1}$ Faculty of Health and Social Sciences, University of South Bohemia in České Budějovice, \\ kajanova@zsf.jcu.cz,
}

\begin{abstract}
Background: The article is aimed at pointing out that the health literacy of people living below the poverty line is at a very low level. Available research shows that there are a lot of indicators influencing health literacy. They can include age, gender, place of residence, and education, which is one of the most important indicators. Methods: The main aim of our research was to evaluate on ascertain the health literacy of representative sample of low-income population. Quantitative strategies were used for research. We used short standardized form of the Health literacy questionnaire. The data collection took place in the course of 2017 and the study included 300 respondents in total. We received 254 valid answers through purpose selection and the snowball technique and analyzed results using SPSS software. Results: The results of our study show an inadequate and problematic health literacy in $58.4 \%$ of the respondents. We compared socio-demographic indicators with health literacy and found actually a statistically significant relation between education and health literacy and between health condition and health literacy. Conclusion: We find that the health literacy should be strengthened, not only in the group in question, but in the population in general, as their health literacy is inadequate either.
\end{abstract}

Keywords: health literacy; poor people; poverty line; health condition; poverty

\section{Introduction}

Many studies are devoted to populations living below the poverty line; additionally, perspectives from which the group can be viewed keep changing. It is obvious for researchers to pay attention to the poor, as poverty-related problems are on the increase and often change their form. The issue of health literacy acquires importance, as it has been proven that low health literacy may lead to lower care for own health and that it may have an important share in more hazardous lifestyle (Wolf, Gazmararian, Baker, 2007). All such criteria may lead to increased morbidity and to a low effort for prevention related to one's own person (Nutbeam, 2000). Therefore, it is important to pay attention to health literacy and to try to increase it where it is low (DeWalt, Berkman, Sheridan et al., 2004).

\subsection{Poverty}

The definition of poverty is still very difficult and there are many such definitions (Van Praag, Ferrer-i-Carbonell, 2008). Poverty is also differently perceived in different countries of the world (Krebs, 2007). The worldwide most frequently used poverty line is 1 dollar per day (Edward, 2006; Ravallion, Chen, Sangraula, 2009). There are many causes of poverty (Rynell, 2008). Three of them are most frequent. Structural cause, where poverty results from family background and upbringing. Individual cause influenced only by the individual in question. Cyclic poverty passed from generation to generation and leading to a so called poverty culture (Krebs, Durdisová, 1997). We can most frequently find two types of poverty in studies and in expert literature. Specifically, objective and subjective poverty. 


\section{Pomáhajúce profesie, roč. 2, č. 1, 2019, 5-16}

Objective poverty (also called income poverty) is delimited by factors independent of the opinion of the poor. It can be divided into absolute and relative poverty. Absolute poverty is focused on consumption (Ravallion, Chen, Sangraula, 2009). Lack of funds makes satisfaction of basic vital needs impossible, so that the individual's existence may be endangered, up to the danger of death. The breadline - the funds allowing the satisfaction of only the most fundamental needs at the level of mere survival - is the limit here. Relative poverty is focused on income (Nándori, 2011). The individual can satisfy one's basic vital needs, but not at a level that is quite common to other people and to the given society (Marks, 2007). Such individual feels deprived (Kukla, 2016). Objectiveness means measurability. To be measurable, it must be exactly and clearly defined by an authority or by a legal standard or based on clear measurable criteria - the consumption and the income. On the other hand, subjective (perceived) poverty is based on the individual's or the household's assessment (Niemela, 2008). People subjectively feel or don't feel poor. However, such poverty does not serve to define the official poverty line and it should rather be considered additional (Van Praag, Ferrer-i-Carbonell, 2008).

In the Czech Republic, the breadline is officially defined as the poverty line. A minimal socially acceptable consumption basket is defined. Due to objectification of poverty for research needs, we consider low-income population the persons who are entitled to material need benefits. The system of help in material need is governed by Act No. 111/2006 Coll., on help in material need. It is a form of assistance to persons with insufficient income, motivating the persons to actively search for the means to satisfy their vital needs. It constitutes one of the measures used by the Czech Republic to fight against social exclusion. It is based on the principle that each person who works should live better than a person who does not work or avoids work. According to the Act material need describes situations related to insufficient provision of basic subsistence, housing and extraordinary events. In essence, situations in which the persons do not have sufficient income and their general social and material situation does not allow the satisfaction of basic life needs, while at the same time, the income cannot be increased due to objective reasons (through own work, through raising claims and receivables, through sale or use of assets). For the purpose of assessing material need, the income and the social and material situation of the relevant person are assessed together with the situation of other (jointly assessed) persons. By the end of 2017, the benefits were drawn by 140000 persons. During the first three quarters of 2017, the expenses for benefits amounted to 3.79 billion CZK. For the same period of 2016, almost one billion more was spent. The reasons for the drop include a higher employment rate and increased wages (MPSV, 2017).

\subsection{Health literacy}

The WHO defines health literacy as "the cognitive and social skills which determine the motivation and ability of individuals to gain access to, understand and use information in ways which promote and maintain good health" (Kickbusch, Pelikan, Apfel, Tsouros, 2013). Therefore, health literacy can be understood as a set of skills of understanding and transferring health information. Health literacy is a specific complex set of capabilities. Communication is one of the capabilities (Zarcadoolas, Pleasant, Greer, David, 2012). Health literacy includes the skill to pass the information correctly, to receive it correctly and to handle it correctly, including preventing the risk or disease origination or spreading (Osborne, 2012).

As Holčík (2010) states, the main contribution of health literacy consists in the fact that it helps people to improve and care for their health. Health literacy strengthens the citizen's capabilities of making decisions of their health and lives, improves their self-confidence and reinforces their dignity (Holčík, 2015). The development of health literacy is influenced by different institutions in the course of life. In childhood, it is primarily the family and the school curriculum in education 


\section{Pomáhajúce profesie, roč. 2, č. 1, 2019, 5-16}

towards health. Further, preventive programs, physicians and the media play a role (Hayes, et al., 2007). Health literacy should not be only a matter of the individual, but also of the state and its health care policy (Kučera, 2015; Hamplová, et al. 2015). However, individual health literacy programs must be adapted to the particularities of different target groups. Their lifestyle and life conditions must be considered as well (D'Eath, Barry, Sixsmith, 2012). Ethnic and cultural differences should also be taken into question (Levin-Zamir, Wills, 2012). The health literacy level is further influenced by several different factors. The crucial ones include education, age, gender, socio-economic status and employment (HLS-EU Consortium, 2012). Research suggests that education is the most important of all health literacy factors (Matsuyama, et al., 2011). There is a general interconnection between general literacy and health literacy (Kickbusch, 2001). The average health literacy of adults increases proportionally to each higher level of education, starting from secondary school (Kutner, Jin, Pausen, 2006). It is therefore logical that groups of the population with lower education do not understand information materials concerning prevention and health care issues (Cotugna, Vickery, Carpenter-Haefele,2005).

Age is another important factor influencing health literacy. Available data suggest that health literacy decreases with increasing age (Kučera, 2015); a dramatic drop is registered after 65 years of age (Kutner, Jin, Pausen, 2006), which can be explained for example by decreasing cognitive functions (Cotugna, Vickery, Carpenter-Haefele,2005). Different studies generally show higher health literacy for women as compared to men (Kutner, Jin, Pausen, 2006).

\subsection{Health literacy of the poor}

As for socio-economic status and employment, the group of adults living below the poverty line must be mentioned. Those persons have lower health literacy than other stratification groups of the population (Kutner, Jin, Pausen, 2006). Their health literacy is worse not only when compared with high-income groups inside the country, but it turns out that GDP of different countries is relevant as well. Countries which have lower GDP than other countries have a lower level of health literacy as well (Wagstaff, 2002). Unfortunately, it is well known that low-income people have worse access to care for both physical and for mental health (Kruk, Goldmann, Galea, 2009). As Dilmaghani (2017) states, poverty is actually a statistically significant predictor of worse mental and physical condition.

Low-income population do not observe the physician's suggestions (White, 2015). Another problem consists of not picking up the medicines and not recognizing the doctor's authority; they rather consider the doctor an advisor, not an expert; if the doctor prescribes them some medicines for their disease, they decide by themselves whether they really do or don't need them (Mojžíšová, Dvořáčková, Kajanová, 2017). As for taking medicines, they often do not pick them up because they are too expensive for them (White, 2015). According to the OECD report, the use of health care differs depending on the level of income (ČTK, 2012).

So, health literacy of low-income population is very low. It often includes poor sanitary habits, not presenting themselves to regular preventive checks and not registering at general practitioners. The probability of going to a physician, particularly to a specialized physician, is higher for persons from higher-income households. Lower-income people rather go to general practitioners, but they omit free preventive checks, in spite of being aware of that option (ČTK, 2012).

Low health literacy can be seen also in their lifestyle. Socially weaker persons tend more to be abusing habit-forming substances, like smoking and drinking of alcohol (Holčík, 2017). Low health literacy is often accompanied by higher expenses on health care in the area of chronic diseases (Dilmaghani, 2017). People with low health literacy go to a specialist only in advanced stage of disease, and the expenses for treatment are higher due to it. The problem with socially weaker 


\section{Pomáhajúce profesie, roč. 2, č. 1, 2019, 5-16}

population also consists in them not changing their life style after expensive therapy, and easily falling ill again (Holčík, 2017).

Bad eating habits constitute another important issue of low health literacy of low-income population. Because of low income and high costs for satisfaction of current needs, they eat cheaply rather than correctly. They go to fast food restaurants more often, they buy food with low nutritional value and cook with analogues. Such factors have a significant impact on poor people's health and mortality (Drewnowski, Specter, 2004)

Two research questions were defined for the study: What health literacy do low-income population in the South Bohemian Region have and what factors influence the health literacy of low-income population.

Our study was focused on the following socio-demographic variables: age, gender, place of residence, education.

\section{Materials and Methods}

The data collection for the group of inhabitants of the South Bohemian Region living below the poverty line took place during the course of 2017. The research set consisted of persons entitled to material need benefits. There are multiple views on how to measure poverty; we focused on objective measurement and in the Czech Republic, objective poverty is determined by the right to get the material need benefit. The benefit serves to cover the basic needs of low-income persons. Breadline serves as the base to assess the right to get the benefit; the breadline is the minimum socially recognized limit of monthly income to cover the basic needs like food, clothing and hygiene. The amount changes every year. This was the selection criterion. In South Bohemia there were 2 492 people (population) in material need by 31. 12. 2017. By confidence interval 5,31 and confidence level was $95 \%$. Due these criteria we counted that we needed 300 respondents. They were approached through purpose selection, combined with snowball technique. We received 254 completely filled-in questionnaires.

To meet the goal, we used a short form of the standardized Health Literacy questionnaire including 16 items. 3). The questionnaire was used on recommendation of the State Health Institute which has also provided us with the questionnaire. The State Health Institute has worked with the questionnaire in other studies concerning health literacy of different target populations. For example, the respondents were asked how easy it was for them to find information on disease therapy, on disease prevention; how easy it was for them to understand the advice from the physician, from the pharmacist, from the media or from their friends. The respondents recorded their answers in five-level Likert scale.

The items served to calculate the index characterizing their health literacy (HL score). Thus, the resulting scale for the short questionnaire has 16 levels, ranging from 0 to 16 . Based on that scale, three basic levels of health literacy are defined: 1) inadequate health literacy (0-8 points); problematic health literacy (9-12 points) and sufficient health literacy (13-16 points). The questionnaire was complemented with several own questions of socio-demographic character.

The questionnaire was administered in the form of a structured interview to arrange better understandability for the target group. The questionnaire was administered by trained interviewers from among academic members of the research team. The research took place in the respondents' natural environment.

Subsequently, the questionnaires were statistically processed in the SPSS program, using the chisquare test and correlation. The established level of significance was $95 \%$. All subjects gave their informed consent for inclusion before they participated in the study. The study was conducted in 
accordance with the Declaration of Helsinki, and the protocol was approved by the Ethical commission Faculty of Health and Social Sciences (SDZ2016, ZGO2016_001).

\section{Results}

\subsection{Health literacy of citizens living below poverty line}

The average score of health literacy in our group amounted to 9.8 points, which is a problematic health literacy. The minimum was 0 , the maximum 16 . Table 1 below shows the distribution of the health literacy index in the target group. $30.7 \%$ respondents were found to have inadequate health literacy; less than one third $(27.7 \%)$ had problematic health literacy and the remaining $26.3 \%$ show sufficient health literacy.

Table 1. The distribution of health literacy in a group of people living below the poverty line.

\begin{tabular}{lll}
\hline Distribution HL score & Frequency & Percent \\
\hline Inadequate HL (0-8 points) & 92 & 30,7 \\
\hline Problematic HL (9-12 points) & 83 & 27,7 \\
\hline Sufficient HL (13-16 points) & 79 & 26,3 \\
\hline Total & 254 & 84,7 \\
\hline
\end{tabular}

Source: Health Literacy of Selected Population Groups of South Bohemian Region SDZ2016, ZG02016_001.

\subsection{Socio-demographic indicators versus health literacy coefficient}

Furthermore, we compared health literacy to age, education, place of residence, health condition, gender, job and marital status. We found that there was a significant relation between education, health condition and health literacy in our target group. On the contrary, the age, gender, job, marital status or place of residence did not have any statistically significant impact on the health literacy of our target group; $\mathrm{p}$ was always higher than 0.05 . That means that the health literacy is not influenced by the respondent living in the city or in the country, being employed or selfemployed, being married, divorced, single or widowed. None of the above-mentioned features had impact on health literacy.

As for education, we found a significant relation, a strong correlation, $\mathrm{p}=0.000, \mathrm{r}=0.335$. That means that persons with higher education had better health literacy.

Health condition is also strongly related to health literacy, $p=0.000, r=-0.338$. We found that persons who considered their health condition as better had higher health literacy.

\subsection{Socio-demographic indicators versus sub-items of the questionnaire}

The questionnaire included 16 questions inquiring for example how easy it was for the respondent to find information on therapy, psychological help, professional help, and how easy or difficult it was to understand the information from specialists, physicians or pharmacists. We tried to find whether any question was statistically dependent on any of the socio-demographic aspects.

As for gender, job and place of residence, we did not find any statistically dependent questionnaire questions.

As for age, education and health-condition, we also assessed 16 questionnaire questions, but only four of them had a correlation coefficient higher than 0.3 and they concerned only the relation to health condition. Furthermore, we found several questionnaire questions with very weak correlations. 
As for age, we found only very weak correlations. The questionnaire questions which were at least a little statistically significant for us, were the following questions:

„How easy is it for you to find information about the therapy of a disease? “, $p=0.000, r=0.213$ and

„How easy is it for you to find information about activities beneficial to mental health? “, $\mathrm{p}=0.000, \mathrm{r}=0.241$.

As for education, we found no statistically significant correlation, only very weak correlations at the following questions:

„How easy is it for you to find information about the therapy of a disease? “, $p=0.000, r=0.257$.

„How easy is it for you to understand what your physician tells you? " $p=0.000, r=-0.260$.

As for the relation between the health condition and health literacy, we found that there was a strong statistical dependence at the following questions:

„How easy is it for you to find information about the therapy of a disease? “, $p=0.000, r=0.392$.

And "How easy is it for you to find information about activities beneficial to mental health? ", $\mathrm{p}=0.000, \mathrm{r}=0.316$.

Another statistical dependence was found at the question: „How easy is it for you to understand the advice concerning health from your family members or friends? ", $p=0.000, r=0.351$.

The last statistically significant question was: „How easy is it for you to understand the information how to become healthier from the media? ", $p=0.000, r=0.311$.

Very weak correlations were found at the following questions:

„How easy it was for you to find where professional help can be found? " $p=0.000, r=0.292$,

„How easy is it for you to understand what your physician tells you? " $p=0.000, r=0.276$.

„How easy is it for you to assess what components of your daily behaviour are related to health? “ $\mathrm{p}=0.000, \mathrm{r}=0.292$

„How easy is it for you to make use of the information provided by the physician in making decisions related to your disease?" $\mathrm{p}=0.000, \mathrm{r}=0.264$ 
Table 2 - Correlation between variables and questions from the questionnaire

\begin{tabular}{|l|c|c|}
\hline Variable X question & $\boldsymbol{p}$ & $\boldsymbol{r}$ \\
\hline Age X How easy is it for you to find information about the therapy of a disease? & 0,000 & 0,213 \\
\hline $\begin{array}{l}\text { Age X How easy is it for you to find information about activities beneficial to } \\
\text { mental health? }\end{array}$ & 0,000 & 0,241 \\
\hline $\begin{array}{l}\text { Education X How easy is it for you to find information about the therapy of a } \\
\text { disease? }\end{array}$ & 0,000 & 0,257 \\
\hline $\begin{array}{l}\text { Education X How easy is it for you to understand what your physician tells } \\
\text { you? }\end{array}$ & 0,000 & $-0,260$ \\
\hline $\begin{array}{l}\text { Health condition X How easy is it for you to find information about the } \\
\text { therapy of a disease? }\end{array}$ & 0,000 & 0,392 \\
\hline $\begin{array}{l}\text { Health condition X How easy is it for you to find information about activities } \\
\text { beneficial to mental health? }\end{array}$ & 0,000 & 0,316 \\
\hline $\begin{array}{l}\text { Health condition X How easy is it for you to understand the advice concerning } \\
\text { health from your family members or friends? }\end{array}$ & 0,000 & 0,351 \\
\hline $\begin{array}{l}\text { Health condition X How easy is it for you to understand the information how } \\
\text { to become healthier from the media? }\end{array}$ & 0,000 & 0,311 \\
\hline $\begin{array}{l}\text { Health condition X How easy it was for you to find where professional help } \\
\text { can be found? }\end{array}$ & 0,000 & 0,292 \\
\hline $\begin{array}{l}\text { Health condition X How easy is it for you to understand what your physician } \\
\text { tells you? }\end{array}$ & 0,000 & 0,276 \\
\hline $\begin{array}{l}\text { Health condition X How easy is it for you to assess what components of your } \\
\text { daily behaviour are related to health? }\end{array}$ & 0,000 & 0,292 \\
\hline $\begin{array}{l}\text { Health condition X How easy is it for you to make use of the information } \\
\text { provided by the physician in making decisions related to your disease? }\end{array}$ & 0,000 & 0,264 \\
\hline
\end{tabular}

Source: Health Literacy of Selected Population Groups of South Bohemian Region SDZ2016, ZG02016_001.

\section{Discussion}

The area of public health care experiences great progress and continuous development, the upswing of knowledge, technologies and progress in the therapy of diseases and the prolongation of mean lifespan. But we are asking the question whether it would perhaps be more beneficial to focus on the development of the individual's capability of maintaining the body healthy as long as possible and to extend the time before having to make use of the services of physicians and health care workers. That means, to emphasize the reinforcement of education towards health, the improvement of preventive programs, the investment of funds in enlightenment and thus in health literacy of current and future generations. The individual should primarily be led to that by the family and by the school, with the help of preventive programs, etc. (Hayes, et al., 2007), and last but not least, the systematic work at increasing the health literacy should also be executed by the state. Kučera (2015), Hamplová, et al. (2015) agree with it. Not only being able to treat patients, but also involving all citizens more intensively in self-care for their health is important (Holčík, 2010). Unfortunately, our results show that the group of people living below the poverty line is very poorly informed about the above stated field. We found that $58.4 \%$ respondents had inadequate and problematic health literacy. The study by Sheridan et al. (2011) accordingly, considers the low-income group more vulnerable. Burghardt (2013) agrees with it as well, stating that most Americans with low health literacy have low income too. 


\section{Pomáhajúce profesie, roč. 2, č. 1, 2019, 5-16}

Unfortunately, the adult population in the Czech Republic has a similar situation, according to the Health Literacy Institute (2017), as $59.4 \%$ of the Czech adult population have inadequate or problematic health literacy. According to a comparison with eight EU countries, the Czech Republic ranks last but one. The results on the general population of the Czech Republic come from the National Health Literacy Institute which belongs to the Health Institute. However, the Institute deals only with the general population.

We think that the inadequate health literacy of the low-income population and of the whole Czech population is caused by the fact that targeted preventive programs in this field are missing. Primary prevention should take place at elementary schools and be intended for broad public; that would increase the level of information of all classes of population

Our study was focused on the statistical relation of health literacy and socio-demographic data gender, place of residence, age, education and job, as we assume that those socio-demographic data can have a great influence on health literacy. The HLS-EU CONSORTIUM study (2012) was based on the same considerations. However, our study found that there is no statistical dependence between health literacy, age, job and place of residence, although we had assumed that people living in cities would have higher health literacy than people living in the country. That finding is in compliance with the study by Furuya et al. (2015) that did not confirm any relation in that respect, and that health literacy did not depend on the respondents' place of residence.

Furthermore, we had assumed that the health literacy would decrease with age, as stated by Kučera (2015), Kutner, Jin, Paulsen (2006) and Cotugna, Vickery, Carpenter-Haefele (2005). However, such dependence was not found in our study, and the age of our target population did not have any impact on their health literacy.

Many studies also speak of higher health literacy of women as compared to that of men (Kutner, Jin, Paulsen, 2006); however, that relation was not confirmed by our study and we cannot state that gender has an influence on the health literacy of the group of poor people.

On the other hand, we found that health literacy is related to education. We took account of the fact that education can be viewed as one of the most important factors of health literacy in general (Matsuyama, 2011), as there is a significant relation between general literacy and health literacy (Kickbusch, 2001). According to Kutner, Jin, Paulsen (2006) average health literacy increases with each further education level acquired, starting from secondary school.

It can thus be stated that people with higher education, or A levels, higher professional or a university education have demonstrably higher level of health literacy. On the contrary, respondents with elementary or even unfinished education have the lowest level of health literacy. Our study confirmed it. Respondents with higher education demonstrably had better health literacy.

Furthermore, the respondents assessed their health condition and we found out that those who assessed their health condition as good had higher health literacy. We believe that health literacy is logically related to eating habits. People with basic information on healthy nutrition will care for good eating habits, won't buy food with zero nutritional value or eat in fast food restaurants. Such bad eating habits are often exhibited by low-income populations, excluded people (Kozubík, 2013), their health and affecting thus their mortality rate (Drewnowski, Specter, 2004). Although there are many studies focused on different target populations, we can see weaknesses in the research of marginalized persons and different ethnic minorities. The said populations should be dealt with in further research studies.

The limitations of the study 
The research was not designed for the whole Czech Republic, but only for the South Bohemian Region. As for the limits of the research tool. Although it was a standardized questionnaire, its complexity was difficult to understand for the research group.

\section{Conclusion}

Thanks to our study, we were able to confirm certain findings from European and international studies. On the other hand, some of our results did not correspond with them. The most striking contradiction was that our study did not record the influence of age and gender on health literacy, while many foreign studies reported this effect (for example Kutner, Jin, Paulsen (2006) and Cotugna, Vickery, Carpenter-Haefele (2005).

Our study confirmed that the low-income population have poor health literacy as well as the general Czech population. It should be noted that the poor differ in some of the major sociodemographic factors influencing health literacy.

The Czech Republic is one of the countries with the lowest health literacy in Europe; the health literacy of the low-income population also shows an inadequate level. We suggest paying more attention to the issue in question and starting interventions in health literacy. The education in this field should be increased by the individual, by the family and, to a considerable degree, by the state in the form of prevention programs and intervention. In our opinion, the education in this field should not stop with the end of school attendance, but it should continue until adulthood and until old age.

Authors Contribution: Conceptualization, Formal Analysis, Writing - Original Draft Preparation - Zuzana Řimnáčová; Methodology, Resources, Writing - Review \& Editing - Alena Kajanová

Funding: The article constitutes an output of the Health Literacy of Selected Population Groups of South Bohemian Region SDZ2016, ZG02016_001 Project.

Conflict of Interests: The authors declare no conflict of interest.

\section{References:}

Burghardt, K. J., Bowman, M. R., Hibino, M., Opong-Owusu, B. K. Jr., Pokora, T. D., Reeves, K., et al. (2013). Using educational games to promote the seeking of a pharmacist and to teach key medication use messages: results from an inner city health party. Res Social Adm Pharm, 9(5), 542552.

Cotugna, N., Vickery, C. E., Carpenter-Haefele, K.M. (2005). Evaluation of literacy level of patient education pages in health-related journals. Journal of Community Health, 30(3), 213-219.

ČTK. (2012). Poor people, according to the OECD, go on to prevent less than the rich (Chudí lidé podle OECD chodí na prevenci méně, než bohatí). Mladá fronta [Online] [cited 2019 Feb 2]. Anvailabe from: https://zdravi.euro.cz/clanek/sestra/chudi-lide-podle-oecd-chodi-na-prevencimene-nez-bohati-466331?category=z-domova.

D’Eath, M., Barry, M. M., Sixsmith, J. (2012). Rapid Evidence Review of Interventions for Improving Health Literacy. Stockholm: European centre for disease prevention and control; 2012.

DeWalt, D.A., Berkman, N.D., Sheridan, S. et al. (2004) Literacy and health outcomes. $j$ gen intern med, 19(12), 1228-1239. https://doi.org/10.1111/j.1525-1497.2004.40153.x

Dilmaghani, M. (2007). Financial unhealthiness predicts worse health outcomes: evidence from a sample of working Canadians. Public Health, 144(1), 32-41. 
Drewnowski, A., Specter, S. E. (2004). Poverty and obesity: the role of energy density and energy costs. The American Journal of Clinical Nutrition 79(1), 6-16. https://doi.org/10.1093/ajcn/79.1.6

Edward, P. (2006). The ethical poverty line: a moral quantification of absolute poverty, Third World Quarterly, 27(2), 377-393.

Furuya, Y., Naoki, K., Zentaro, Y., Hideki, H. (2015). Health literacy, socioeconomic status and selfrated health in Japan. Health Promotion International, 30(3), 505-513. https://doi.org/10.1093/heapro/dat071

Hamplová, L., Hulinský, P., Jexová, S., Pekara, J. (2015). The issue of health literacy in the Czech Republic (Problematika zdravotní gramotnosti v ČR). Proceedings of the 10th Scientific Conference with International Participation; 2015 Jun 18; Prague, Czech Republic.

Hayes, M., Rosss, I. E., Gasher, M., Gutstein D., Dunn J.R., Hackett R.A. 2017. Telling stories: News media, health literacy and public policy in Canada. Social Science \& Medicine. 64(9), 1842-1852.

Health Literacy Institute (2017). (Ústav pro zdravotní gramotnost, z.ú. 1). National Conference on Health Literacy (Situation Document) (Národní konference o zdravotní gramotnosti (situační dokument)). 2017. http://www.uzg.cz/akce.html. Accessed 07 May 2018.

HLS-EU Consortium. (2012). Comparative report of health literacy in eight eu member states. In: The European health literacy survey HLS-EU [Online]. [cited 2018 Jun 10]. Availabe from: HTTP://WWW.HEALTH-LITERACY.EU.

Holčík, J. (2010). Health care and health literacy system. (Systém péče o zdraví a zdravotní gramotnost). Brno: Masarykova univerzita.

Holčík, J. (2015). The role of health literacy in health care (Role zdravotní gramotnosti v péči o zdraví) www.cls.cz [Online]. [cited 2019 Jan 26]. Availabe from: http://www.cls.cz/dokumenty/sem_role_zdravotni_gramostnosti.pdf.

Holčík, J. (2017). Health literacy is a priority of health care (Zdravotní gramotnost je prioritou péče o zdraví). Praha: Ústav pro zdravotní gramotnost z.ú.

Kickbusch, I. S. (2001). Health literacy: addressing the health and education divide. Health Promotion International, 16(3), 289-297.

Kickbusch, I., Pelikan, J. M., Apfel, F., Tsouros, A. D. (2013). Health literacy - The solid facts; Copenhagen: WHO Regional Office for Europe.

Kozubík, M., van Dijk, J.P., Odraskova, B. (2018). Roma Housing and Eating in 1775 and 2013: A Comparison. Int. J. Environ. Res. Public Health, 15(4), 588.

Krebs, V. Durdisová, J. (1997). Social Policy (Sociální politika). Praha: Codex Bohemia.

Krebs, V., et al. (2007). Social Policy (Sociální politika). Praha: Aspi.

Kruk, M. E., Goldmann, E., Galea, S. (2009). Borrowing And Selling To Pay For Health Care In LowAnd Middle-Income Countries. Health Affairs, 28(4), 1056-1066.

Kučera, Z. (2015). Health literacy of the Czech population: Results of a representative survey (Zdravotní gramotnost české populace: Výsledky reprezentativního šetření). www.szu.cz [Internet]. [cited 2017 April 26]. Availabe from: http://www.szu.cz/uploads/documents/czzp/Efektivni strategie_podpory zdravi 18062015/Zdr avotni gramotnost ceske populace Vysledky reprezentativniho setreni.pdf 
Kukla, L. (2016). Social and preventive pediatrics in the current concept (Sociální a preventivní pediatrie v současném pojetí). Praha: Grada Publishing.

Kutner, M. G., Jin, Y., Pausen, C. (2006). The Health Literacy of America's Adults: Results From the 2003 National Assessment of Adult Literacy. U.S. Department of Education: Washington, DC: National Center for Education Statistics.

Levin-Zamir, D., Wills, J. (2012). Health literacy, culture and community. In: Begoray, D.; Gillis, D.E.; Rowlands, G., eds. Health literacy in context: international perspectives. Hauppauge, NY, Nova Science Publishers: 99-123.

Marks, G. N. (2007). Income Poverty, Subjective Poverty and Financial Stress. Australian Government Social Policy Research Paper. 2007, 29. Available at SSRN: https://ssrn.com/abstract=1728587

Matsuyama, R. K., Wilson-Genderson, M., Kuhn, L., Moghanaki, D., Vachhani H., Paasche-orlow, M. (2011). Education level, not health literacy, associated with information needs for patients with cancer. Patient Education and Counseling, 85(3), 229-236.

Mojžíšová, A., Dvořáčková, D., Kajanová, A. (2017). Selected aspects of health literacy in clients at risk of poverty (Vybrané aspekty zdravotní gramotnosti u klientů ohrožených chudobou). Kontakt, 3, 213-218.

MPSV: Expenditure on emergency benefits has fallen sharply this year. (Data MPSV: Výdaje na dávky v nouzi letos výrazně poklesly). České noviny [online]. 2017 [cited 2018 Jul 12]. Available from: http://www.ceskenoviny.cz/zpravy/data-mpsv-vydaje-na-davky-v-nouzi-letos-vyraznepoklesly/1551535. Accessed 02 June 2018.

Nándori, E. S. (2011). "Subjective Poverty and Its Relation to Objective Poverty Concepts in Hungary," Social Indicators Research. An International and Interdisciplinary Journal for Quality-ofLife Measurement, Springer, 102(3), 537-556, July.

Niemela, M. (2008). Perceptions of the Causes of Poverty in Finland. Acta Sociologica, 51(1), 23-40.

Nutbeam, D. (2000). Health literacy as a public health goal: a challenge for contemporary health education and communication strategies into the 21st century, Health Promotion International, 15(3), 259-267, https://doi.org/10.1093/heapro/15.3.259

Osborne, H. (2012). Health Literacy From A to Z. Burlington: Jones \& Bartlett Publishers.

Ravallion, M., Chen, S., Sangraula, P. (2009). Dollar a Day Revisited. The World Bank Economic Review, 23(2), 163-184.

Rynell, A. (2008). Causes of poverty.

Sheridan, S.L., Halpern, D.J., Viera, A. J., et al. (2011). Interventions for individuals with low health literacy - A systematic review. J Health Commun, 16(3), 30-54.

Van Praag, B. M. S, Ferrer-i-Carbonell, A. A. (2008). Multidimensional Approach to Subjective Poverty. In: Kakwani N, Silber J, editors. Quantitative Approaches to Multidimensional Poverty. Measurement. Palgrave Macmillan: London, p. 135-154.

Wagstaff, A. A (2002). Poverty and health sector inequalities. Bulletin of the World Health Organization, 80(2), 97-105.

White, R. et al. (2015). Health communication, self-care, and treatment satisfaction among lowincome diabetes patients in a public health setting. Patient Education and Counseling, 98(2), 144149. 
Pomáhajúce profesie, roč. 2, č. 1, 2019, 5-16

Wolf, M. S., Gazmararian, J.A., Baker, D. W. (2007). Health literacy and health risk behaviors among older adults. Am J Prev Med, 32(1), 19-24. doi: 10.1016/j.amepre.2006.08.024

Zarcadoolas C.H., Pleasant, A., Greer, A., David, S. (2012) Advancing Health Literacy: A Framework for Understanding and Action. Hoboken: John Wiley \& Sons. 